\title{
Analysis of the Influencing Factors on the Farmers' Take-up of Greenhouse Agricultural Insurance Cover: A Case Study
}

\author{
Ercan Ozen ${ }^{1}$, Simon Grima ${ }^{2}$
}

\begin{abstract}
:
The purpose of this study is to analyse the insurance claims and insurance intentions of the farmers who are engaged in greenhouse cultivation and to determine the influencing factors affecting the insurance process.

Various methods were used in the study since results obtained from one source were deemed insufficient in explaining the insurance behaviours of farmers. These included a survey, interview, document analysis and a literature review. The survey data was analysed using basic statistics and ANOVA.

Findings indicate that that the intention of the farmers to take an greenhouse agricultural insurance coverage is not influenced by factors relating to the experience of previous damages, positivity, reason, and facilitation. However, it is influenced by factors relating to the farmers' attitude and the obstacles they face.

The most prominent influential factors preventing farmers from purchasing agriculture insurance are physical problems (1) derived from insufficient resources, (2) property and deed-title issues in greenhouse areas and (3) the problems regarding damage payments.

It is emphasised that insurance-related problems can be solved by a macro-scale agricultural reform and communication between the relative parties. These findings can be used as a tool in policy development by farmers, insurance institutions and related government institutions.
\end{abstract}

Keywords: Agriculture insurance, greenhouse cultivation, farmer.

JEL Codes: G20, Q14, Q12.

\footnotetext{
${ }^{1}$ University of Uşak,department of Banking and Finance, Turkey, ercan.ozen@ usak.edu.tr

${ }^{2}$ University of Malta, Head Insurance Department, Faculty of Economics, Management and Accountancy, corresponding author, simon.grima@um.edu.mt
} 


\section{Introduction}

As the world population is increasing, the adequate and healthy nutrition of the population becomes very important since food is a continuous need for human beings. Therefore, it is also necessary to ensure sustainable agricultural activities by farmers. As in other forms of agriculture, greenhouse cultivation is also under threat and faces risks. Heavy rainfall, strong winds, tornados, frost and diseases are among the risks that farmers are exposed too. If one of these risky events occurs, the number of products from the harvest and income from these products are seriously reduced. This also endangers the sustainability of family-owned greenhouse cultivation. Agriculture insurances are important to provide a hedge against these risks, by risk transfer, to ensure the agricultural business damage cover and continuity. In greenhouse cultivation, products are to be cultivated under special conditions. Due to their structure, greenhouses differ from the cultivation environment of other agricultural products and therefore the possibility of damage is high.

It is difficult for the farmers who are engaged in greenhouse cultivation to continue their agricultural activities and suffer the damages due to natural conditions. In order to maintain this production potential, an insurance system is necessary to cover the losses due to damages that might occur. This will ensure market stability in the food sector and potential good safety. To ensure that farmers take up insurance cover, insurance underwriters should consider the opinions of farmers and the problems they face. (Nikolov et al., 2013).

Greenhouse insurance in Turkey operates as a sub-unit of the insurance system, which was founded under the name of Agriculture Insurance Pool (Tarsim). The risks arising due to different reasons to physical equipment and products in greenhouses are secured by this Tarsim's premium pool. Farmers' insurance premium payments are supported by the state, and half of the premium costs are covered by the government ${ }^{3}$. In addition, an exemption system that aims to lower the price of insurance premium cost was designed. Natural disasters suffered by farmers in the past and the damages in the agricultural fields are expected to increase the need for insurance. Given the importance and need to ensure sustainability of greenhouse cultivation, the authors' aim, with this article to highlight and analyse the influencing factors leading farmers engaged in greenhouse cultivation, to take up an insurance cover.

\section{Literature review}

Farmers' viewpoints and attitudes towards agriculture insurances have been a subject of many types of research in different countries of the world, such as those by Malini

\footnotetext{
${ }^{3}$ http://www.tarsim.gov.tr. (accessed: 10.05.2018).
} 
(2011), Tsikirayi et al. (2013), Jin et al. (2016), Sibiko et al. (2017), Nikolov et al. (2013), Tan et. al. (2012), Baldacchino et al. (2017) and (2018).

Malini (2011) in her study carried out 60 farmers in India (Ambasamudram Area of Tamil Nadu) identified that the takeup and implementation of agriculture insurance depended largely on the farmers' attitude. She revealed that farmers had positive attitudes towards agricultural insurance and noted that factors such as (1) having reasonable premium rates, (2) eased formalities, (3) guidance by staff and (4) coverage of the certain losses in agriculture insurance were important to ensure takeup of agricultural insurance cover.

In a study conducted in Zimbabwe by Tsikirayi et al. (2012), it was noted that damage experiences positively influenced a farmer's decision to take up agriculture insurance. Therefore, it was recommended that increasing the awareness of risk and insurance among farmers and developing insurance products and services that meet the customer needs are important factors to influence insurance take-up.

Sibiko et al. (2017), in their study conducted in Kenya, suggested that (1) better education for farmers, (2) more transparent systems, (3) insurance policy offers for small groups instead of individual farmers would increase the desire for weather index insurance (WII). These WIIs could lessen the high costs of transactions in traditional, indemnity-based agricultural insurance products and could, therefore, be important for the small farmers in developing countries. This reasoning was echoed by Jin et al. (2016), who in their study on the insurance of weather changes index in China, added that (1) risk avoidance levels, (2) beliefs, (3) educational levels, (4) size of properties of farmers and (5) the income, had an effect on insurance take-up.

Aydın and Koç (2016), in a study carried out in Turkey assert that there are communicational problems to be solved in the marketing of insurance products. They also highlight that personality characteristics influence the attitude towards and the purchasing of insurance cover.

Nikolov et al. (2013), indicated that the reasons for farmers not taking up insurance cover were (i) unsatisfactory insurance contract conditions, (ii) not believing in the benefit of insurance, (iii) time consuming and delayed compensation payments, (iv) under-developed insurance products and (v) farmers' lack of information about insurance conditions. They also revealed that a significant amount of farmers (55\%) did not intend to purchase insurance in the following year.

A study by Tan et al. (2012) highlights that insurance cover the appetite of farmers who suffered from a natural disaster before are higher than for other farmers. However, they also identified that one of the influencing factors, which prevented farmers from taking-up insurance products, was their low incomes. This reasoning was echoed by Akçaöz et al. (2006), who with their survey carried out in the Eastern Antalya region, where greenhouse cultivation is intense, determined that at least 
$77.6 \%$ of the farmers did not take-up insurance cover because of insufficient income of farmers. However, they added that (1) high insurance premiums and (2) disorder in damage payments also affected the low take-up.

\section{Method, Application and Findings}

\subsection{Sample Characteristics}

Demre county of Antalya was selected as the study field. This is because two years before the study period a tornado was experienced in the county. Demre is a county connected to Antalya on the Mediterranean coast of Turkey. Its population in 2017 was 25,928 and it is estimated that approximately 6,500 farmers live in Demre without considering the elderly (12.45\%), young people (35.64\%) and women $(48.60 \% \text { of the whole population })^{4,5}$.

According to sub-governorship data, protected cultivation (greenhouse cultivation) is carried out in 20.000 declares of protected areas in Demre County. The number of farmers registered in the Farmer Registry System (FRS) is 2,714. However, many farmers are not registered in the FRS and it is estimated that the rate of FRS registered farmers is about $42 \%$. Unlike, the various studies carried out which are based on one method, the authors in this study uses different approaches to collect data, specifically official documents, literature, a self-administered survey, interviews and observation. A methodology also used by Koç and Boz (2014) and (Grima, 2017).

\subsection{Survey}

To develop the self-administered survey, which consisted of 31 statements, 3 yes/no question and 1 demographic question determining the age group; the authors reviewed literature and studies by researchers highlighted above and used a thematic approach (Braun et al., 2006) to extract the sub-headings categorised hereunder for the first 29 statements (Table 1):

Table 1. Survey structure

\begin{tabular}{|l|l|}
\hline Attitude & Farmers' attitude towards Agriculture Insurance (statements 1-7) \\
\hline Positivity & Farmers' positive view of current insurance (statements 8-11) \\
\hline Reasons & Farmer's need for purchasing an insurance cover (statements 12-15) \\
\hline Obstacle & Farmers' problems to take up an insurance cover (statements 16-24) \\
\hline Facilitating & Farmers' recommendations to facilitate purchase insurance cover (statements 25-29) \\
\hline $\begin{array}{l}\text { Advisory } \\
\text { Service }\end{array}$ & $\begin{array}{l}\text { Whether the establishment of a farmer advisory would increase my desire to take up } \\
\text { Tarsim insurance cover (statement 30) }\end{array}$ \\
\hline Intention & Whether the farmers' intend to take on Tarsim insurance cover again (statement 31) \\
\hline
\end{tabular}

\footnotetext{
${ }^{4}$ https://www.endeksa.com/tr/analiz/antalya/demre/demografi, Accessed: 09.05.2018)

5 https://www.endeksa.com/tr/analiz/antalya/demre/demografi, Accessed: 09.05.2018)
} 
This survey was specifically drawn-up for this study and the participants in the first twenty-nine statements were asked to tick the appropriate perception/opinion on a five-point Likert scale being: "I"- absolutely disagree, "2" - I disagree, "3"- I am hesitant, "4" - I agree and "5"-I absolutely agree".

\subsection{Sample Size}

In total, the survey was administered to 644 farmers using a non-probability, purposive and snowballing sampling (Tongco, 2007) to recruit participants, during 2 periods, however, only 281 of the farmers participated in the survey. In the first period between the 15th and 25th January 2018, 192 farmers participated and returned the surveys. In the second period between the 21st and 22nd April 2018, 249 surveys were received. 32 surveys had errors and were excluded from the evaluation and 249 questionnaires were used in the study. The participation rate of the survey was $37.72 \%$ and the analysed survey rate is $33.42 \%$.

\subsection{Official Document Analysis}

The authors also reviewed official documents on the damage payments made by the Prime Ministry and Tarsim in relation to the tornado with occurred between 2016 and 2017 in Demre County.

\subsection{Interview}

After, analysing the data collected from the surveys, the authors decided to dig deeper into the farmers' greenhouse agriculture insurance coverage influencing factors, to better understand the issues they are facing, opportunities that might have been missed through literature and the close-ended survey and to get a feel of the farmers' proposed solution. The authors' felt it is necessary to understand the farmers better and create better communication with them.

Therefore, interviews were performed with 28 farmers during April 2018 in order to obtain more clarity. The authors used a non-probability purposive and snowballing sampling method (Tongco, 2007), to recruit participants. 35 farmers around the region were selected for the interview. After the interview with the first farmer, the farmer introduced the authors to the next farmer and this continued until we started to get similar answers and reached saturation (Morse, 1995). For that reason, the number of interviews was stopped at 28. Only one open-ended question was asked, that is "what are the influencing factors when deciding to take up an insurance cover and the problems that you encounter with the Tarsim Insurance".

The thematic approach as suggested by Braun et al., (2006) was used to select and group the 10 most important answers under different statements that reflected the influential factors for insurance cover take-up and the encountered problems with the Tarism Insurance. 


\subsection{Restrictions of the Study}

The sample was restricted to farmers who engaged in greenhouse cultivation. As discussed in the literature, under normal conditions, the largest influencing factor that could affect farmers for taking up agriculture insurance cover is the expectation of damages that may be caused by natural disasters. This was the reason why the study was restricted to Demre, the county of Antalya, region in which a tornado occurred in 2016 and 2017 consecutively.

Moreover, although, 644 farmers were asked to participate in the survey about agriculture insurance cover, most of the farmers avoided to participate in the survey and answered, using an irritated voice, that they do not understand these things. For that reason, therefore, it was assumed that the majority of the farmers who did not answer the survey questions did not take out an insurance cover.

\section{Findings and Analysis}

\subsection{Survey Findings}

In case of damages to the greenhouses, farmers' demand for insurance is expected to increase. Results show that damages occurred in 125 (50.2\%) greenhouses out of 249 in the last 3 years. However, the number of farmers who took out greenhouse insurance cover in the last three years is $102(41.0 \%)$. The number of farmers having an insurance policy in the period of the survey is $86(34.5 \%)$. Although approximately $14 \%$ of the farmers who took out a greenhouse insurance cover in previous years gave it up, most of the farmers said they would be taking a greenhouse insurance cover in the next years $(56.2 \%)$.

Although there are $61.81 \%$ FRS registered farmers (i.e.154 farmers), only $34.5 \%$ currently have a greenhouse insurance cover. Therefore, it seems that being on the farmer's registry is not a sufficient influencing factor to take out insurance cover (Table 2).

Table 2. Questions 33-35

\begin{tabular}{|l|l|l|l|l|l|}
\hline $\begin{array}{l}\text { Have you had any damages } \\
\text { in the last 3 years? }\end{array}$ & $\mathbf{N}$ & $\mathbf{\%}$ & $\begin{array}{l}\text { Do you have } \\
\text { greenhouse insurance? }\end{array}$ & $\mathbf{N}$ & $\mathbf{\%}$ \\
\hline No & 99 & 39.8 & No & 145 & 58.3 \\
\hline Yes & 125 & 50.2 & Yes & 86 & 34.5 \\
\hline No answer & 25 & 10.0 & No answer & 18 & 7.2 \\
\hline Total & 249 & 100 & Total & 249 & 100 \\
\hline & & & & & \\
& & & & & \\
\hline
\end{tabular}




\begin{tabular}{|l|l|l|l|l|l|}
\hline $\begin{array}{l}\text { Did you get greenhouse } \\
\text { insurance in the last } 3 \\
\text { years? }\end{array}$ & $\mathbf{N}$ & $\mathbf{\%}$ & $\begin{array}{l}\text { Do you think of taking } \\
\text { out an insurance cover } \\
\text { next year? }\end{array}$ & $\mathbf{N}$ & $\mathbf{\%}$ \\
\hline No & 119 & 47.8 & No & 35 & 14.1 \\
\hline Yes & 102 & 41.0 & Undecided & 63 & 25.3 \\
\hline No answer & 28 & 11.2 & Yes & 140 & 56.2 \\
\hline Total & 249 & 100 & No answer & 11 & 4.4 \\
\hline Do you have FRS Number? & $\mathrm{N}$ & $\%$ & Total & 249 & 100 \\
\hline Yes & 154 & 61.8 & Your age & & \\
\hline No & 63 & 25.3 & $18-30$ & 54 & 21.7 \\
\hline No answer & 32 & 12.9 & $31-45$ & 70 & 28.1 \\
\hline Total & 249 & 100.0 & $46-60$ & 82 & 32.9 \\
\hline & & & $61+$ & 16 & 6.4 \\
\hline & & & No answer & 27 & 10.8 \\
\hline & & & Total & 249 & 100 \\
\hline
\end{tabular}

SPSS 18 (Statistical Package for the Social Sciences) was used to verify validity and reliability analysis of the scores obtained from study data. Principle components analysis was performed to group the observed variables related to each other and collect them as a component (Baglin, 2014). The authors show these results in Table 4. The Varimax rotation method has been used in determining the common factor structures. Factor loadings of the items vary between 0.507 and 0.771 . The statements with influencing factor loading under 0.50 in the scale were excluded from the scale. KMO (Kaiser-Meyer-Olkin) values belonging to the data obtained from the scales vary between 0.689 and 0.787 . Therefore, it can be said that the sample volume is sufficient for factor analysis.

According to principal components analysis results, one can note that the data obtained from the scale are valid when we look at the factor loadings of the items (Kim et al., 2010). Bartlett's Test of Sphericity values (p-value 0,000) of all scales is significant. In addition, reliability levels $(\alpha)$ of all scales vary between 0.688 and 0.787 . Table 3 shows the results of the descriptive statistics relating to the statements under the themes described as 'Attitude' (statements 1-7), 'Positivity' (statements 811), 'Reasons' (statements12-15), 'Obstacle' (statements 16-24), 'Facilitating' (statements 25-29), Advisory Service (Statement 30) and Intention (statement 31). Skewness and kurtosis values of the variables are within the ranges of +3 and -3 . Therefore, that data is normally distributed.

Farmers' attitudes towards insurance have a significant role in their request for agriculture insurance. When 2 out of 7 questions in 'Attitude' theme scale are excluded (influencing factor loading under 0.50 in the scale) from the scale, the average score of the scale is 3.048. The worst score on this scale is related to insurance cover formalities (2.7702). This scale score indicates that farmers' formalities should be looked into, and facilitated. In addition, it seems that the farmers show a bit of concern on whether the insurance experts are capable of addressing problems and acting in a fair manner (2.7711). The average score of the 
'Positivity' theme statements on factors that may influence farmers' insurance cover appetite, is 2.204; indicating a not so positivity outlook towards increasing the appetite for insurance cover. Here, one can note above all that farmers view on marketing opportunities is not so bright (2.13779) and they do not believe that they can get a fair price for their products (1.9028), indicating that more work needs to be done to improve product marketing opportunities.

The average score for the statements on 'Reasons' for requiring insurance cover is high at 4.020, indicating that farmers are aware of the need for insurance cover to ensure continuity and to transfer away from the risks of losses due to any possible damages. 'Obstacles' faced by farmers to obtain Tarsim insurance cover show an average score of 3.481 after taking out the 4th and 5th statements from the scale (influencing factor loading under 0.50 in the scale). The most significant influential obstacle to the farmers' take-up of an insurance cover is related to the title deed (3.7318).

The average score of 'Facilitating' we can improve the farmers' appetite for taking insurance cover is 3.850 and the most significant influencing factor is the reduction in premiums at a mean of 4.1045. Moreover, it is perceived that the farmers' advisory centre will increase the desire to take up insurance cover $(4,0776)$ (Advisory Service theme) with their average score for intention to having insurance being a mean of 3,7091 (Intention theme).

Table 3. Descriptive Statistics

\begin{tabular}{|l|l|l|l|l|l|l|l|l|l|}
\hline & $\mathrm{N}$ & Min. & $\begin{array}{l}\text { Max } \\
\text {. }\end{array}$ & Stat. & Stat. & Stat. & Stat. & $\begin{array}{l}\text { Std. } \\
\text { Dev. }\end{array}$ & \multicolumn{2}{l|}{ Skewness } & Stat. & \multicolumn{2}{l|}{$\begin{array}{l}\text { Std. } \\
\text { Error }\end{array}$} & \multicolumn{2}{l|}{ Stat. } & $\begin{array}{l}\text { Std. } \\
\text { Error }\end{array}$ \\
\cline { 2 - 10 } & 249 & 1.00 & 5.00 & 2.9719 & 1.2839 & -.062 & .154 & -1.110 & .307 \\
\hline $\begin{array}{l}\text { Attitude } \\
1\end{array}$ & 248 & 1.00 & 5.00 & 2.7702 & 1.2466 & .204 & .155 & -1.032 & .308 \\
\hline $\begin{array}{l}\text { Attitude } \\
2\end{array}$ & 248 & 1.00 & 5.00 & 3.2258 & 1.1547 & -.339 & .155 & -.778 & .308 \\
\hline $\begin{array}{l}\text { Attitude } \\
3\end{array}$ & 249 & 1.00 & 5.00 & 3.6546 & 1.1540 & -.866 & .154 & -.150 & .307 \\
\hline $\begin{array}{l}\text { Attitude } \\
4\end{array}$ & 248 & 1.00 & 5.00 & 3.1048 & 1.2553 & -.212 & .155 & -1.131 & .308 \\
\hline $\begin{array}{l}\text { Attitude } \\
5\end{array}$ & 245 & 1.00 & 5.00 & 3.0327 & 1.2540 & -.163 & .156 & -1.068 & .310 \\
\hline $\begin{array}{l}\text { Attitude } \\
6\end{array}$ & 249 & 1.00 & 5.00 & 2.7711 & 1.2571 & .146 & .154 & -1.154 & .307 \\
\hline $\begin{array}{l}\text { Attitude } \\
7\end{array}$ & 247 & 1.00 & 5.00 & 2.1377 & 1.2930 & .935 & .155 & -.407 & .309 \\
\hline $\begin{array}{l}\text { Positivit } \\
\text { y 1 }\end{array}$ & 249 & 1.00 & 5.00 & 2.3333 & 1.3034 & .618 & .154 & -.935 & .307 \\
\hline $\begin{array}{l}\text { Positivit } \\
\text { y 2 }\end{array}$ & 248 & 1.00 & 5.00 & 1.9028 & 1.1990 & 1.216 & .155 & .265 & .309 \\
\hline $\begin{array}{l}\text { Positivit } \\
\text { y 3 }\end{array}$ & 249 & 5.00 & 3.9277 & 1.0447 & -1.181 & .154 & 1.040 & .307 \\
\hline $\begin{array}{l}\text { Positivit } \\
\text { y 4 }\end{array}$ & 247 \\
\hline $\begin{array}{l}\text { Reasons } \\
1\end{array}$ & 249 & 5.00 & 2.4677 & 1.2816 & .444 & .155 & -1.096 & .308 \\
\hline
\end{tabular}


Analysis of the Influencing Factors on the Farmers' Take-up of Greenhouse Agricultural Insurance Cover: A Case Study

\begin{tabular}{|l|c|c|c|c|c|c|c|c|c|}
\hline $\begin{array}{l}\text { Reasons } \\
2\end{array}$ & 249 & 1.00 & 5.00 & 4.0161 & 1.0586 & -1.368 & .154 & 1.552 & .307 \\
\hline $\begin{array}{l}\text { Reasons } \\
3\end{array}$ & 248 & 1.00 & 5.00 & 4.1008 & .9659 & -1.671 & .155 & 2.960 & .308 \\
\hline $\begin{array}{l}\text { Reasons } \\
4\end{array}$ & 248 & 1.00 & 5.00 & 4.0121 & 1.0741 & -1.368 & .155 & 1.429 & .308 \\
\hline $\begin{array}{l}\text { Obstacle } \\
1\end{array}$ & 248 & 1.00 & 5.00 & 3.2460 & 1.3163 & -.259 & .155 & -1.035 & .308 \\
\hline $\begin{array}{l}\text { Obstacle } \\
2\end{array}$ & 247 & 1.00 & 5.00 & 3.2915 & 1.2703 & -.430 & .155 & -.931 & .309 \\
\hline $\begin{array}{l}\text { Obstacle } \\
3\end{array}$ & 248 & 1.00 & 5.00 & 3.2177 & 1.2950 & -.333 & .155 & -1.099 & .308 \\
\hline $\begin{array}{l}\text { Obstacle } \\
4\end{array}$ & 248 & 1.00 & 5.00 & 3.5766 & 1.2281 & -.681 & .155 & -.650 & .308 \\
\hline $\begin{array}{l}\text { Obstacle } \\
5\end{array}$ & 247 & 1.00 & 5.00 & 3.5142 & 1.2456 & -.618 & .155 & -.685 & .309 \\
\hline $\begin{array}{l}\text { Obstacle } \\
6\end{array}$ & 248 & 1.00 & 5.00 & 3.6694 & 1.1644 & -.680 & .155 & -.447 & .308 \\
\hline $\begin{array}{l}\text { Obstacle } \\
7\end{array}$ & 249 & 1.00 & 5.00 & 3.6185 & 1.1721 & -.705 & .154 & -.393 & .307 \\
\hline $\begin{array}{l}\text { Obstacle } \\
8\end{array}$ & 219 & 1.00 & 5.00 & 3.5616 & 1.1729 & -.675 & .164 & -.392 & .327 \\
\hline $\begin{array}{l}\text { Obstacle } \\
9\end{array}$ & 220 & 1.00 & 5.00 & 3.7318 & 1.1411 & -.742 & .164 & -.174 & .327 \\
\hline $\begin{array}{l}\text { Facilitati } \\
\text { ng 1 }\end{array}$ & 221 & 1.00 & 5.00 & 3.5430 & 1.1962 & -.585 & .164 & -.629 & .326 \\
\hline $\begin{array}{l}\text { Facilitati } \\
\text { ng 2 }\end{array}$ & 220 & 1.00 & 5.00 & 4.1045 & .9081 & -1.279 & .164 & 1.804 & .327 \\
\hline $\begin{array}{l}\text { Facilitati } \\
\text { ng 3 }\end{array}$ & 219 & 1.00 & 5.00 & 3.9863 & .9696 & -1.252 & .164 & 1.563 & .327 \\
\hline $\begin{array}{l}\text { Facilitati } \\
\text { ng 4 }\end{array}$ & 221 & 1.00 & 5.00 & 3.7511 & 1.0856 & -.867 & .164 & .129 & .326 \\
\hline $\begin{array}{l}\text { Facilitati } \\
\text { ng 5 }\end{array}$ & 221 & 1.00 & 5.00 & 4.1312 & .9224 & -1.491 & .164 & 2.724 & .326 \\
\hline $\begin{array}{l}\text { Advisory } \\
\text { Service }\end{array}$ & 219 & 1.00 & 5.00 & 4.0776 & .93279 & -1.045 & .164 & 1.001 & .327 \\
\hline Intention & 220 & 1.00 & 5.00 & 3.7091 & 1.07564 & -.620 & .164 & -.157 & .327 \\
\hline
\end{tabular}

\subsection{One-way ANOVA Analysis Findings}

One-way ANOVA is used to determine whether there are any statistically significant differences between the means of two or more independent (unrelated) groups, in which the parametrical test assumptions are provided. One-way ANOVA is used to test whether the average of more than two independent entities are equal to each other (Hamarat, 2017).

In this part, the authors highlight the results of the ANOVA analysis, to determine what influence specific factors have on the appetite of farmers to purchase an insurance policy cover. Specifically (i) whether farmers had damages in their greenhouses in the last three years, (ii) attitudes towards agricultural insurance; (iii) conditions that may positively affect farmers' insurance claims; (iv) conditions that may have led to insurance; (v) overcoming the obstacles for insurance (vi) conditions for facilitating insurance. Therefore, hypotheses were created for each possible influential factor and then tested using the one-way ANOVA. 
$H_{0}$ : The intention of the farmers to take on greenhouse agricultural insurance coverage (statement 31) will not change with damage experience in the last three years (statement 32);

$H_{1}$ : The intention of the farmers to take on greenhouse agricultural insurance coverage (statement 31) will change with damage experience in the last three years (statement 32).

Table 4. Validity and Reliability Analysis Results

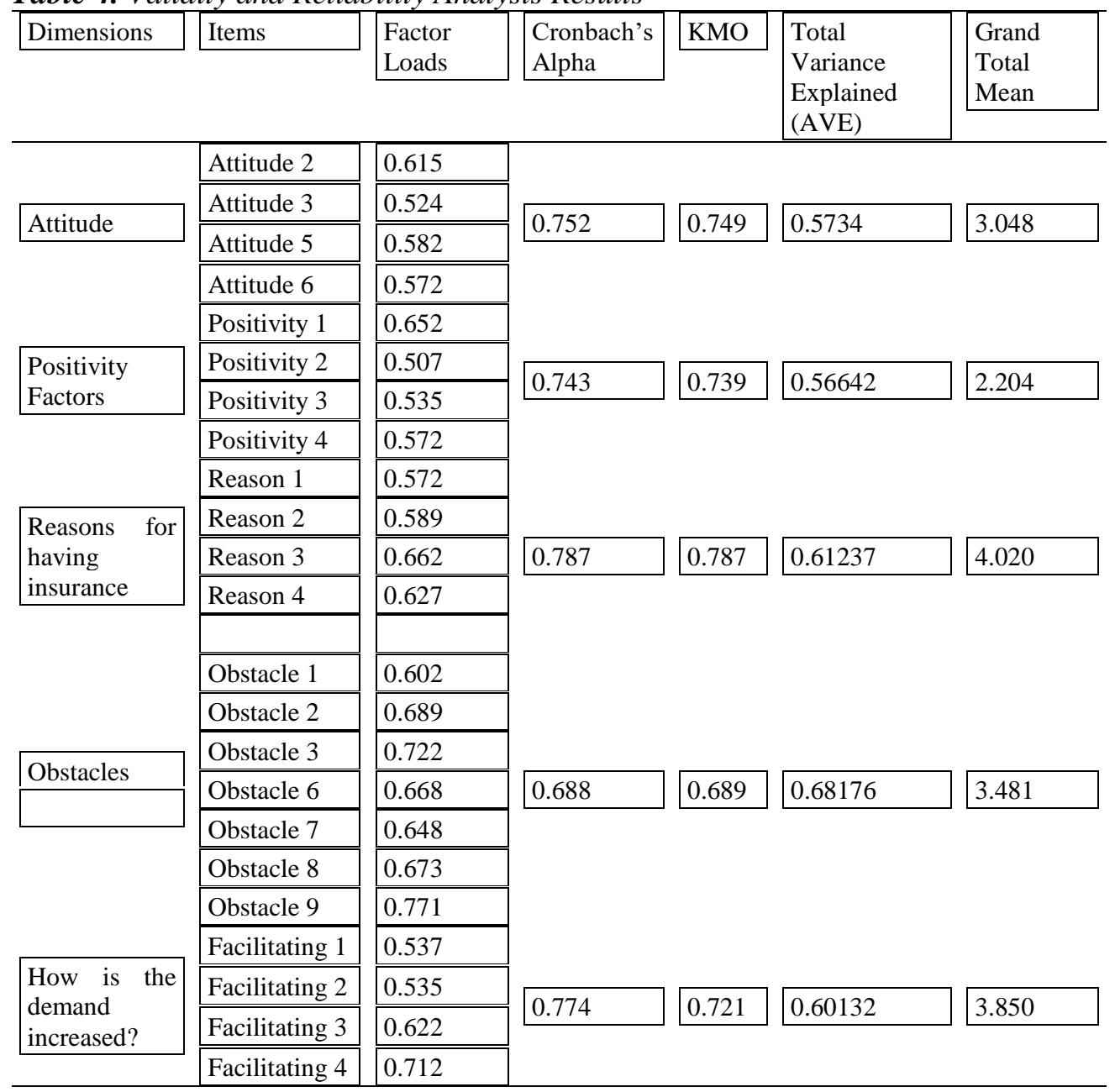

No statistically significant difference was found $[\mathrm{F}(1,218)=0.001, \mathrm{p}=0.978]$, therefore we can accept $\mathrm{H}_{0}$ and confirm that the intention of farmers taking on greenhouse agricultural insurance coverage will not be influenced by damage experience in the last three years.

$H_{0}$ : Having an agriculture insurance coverage (statement 33) will not change with the farmers' damage experience in the last three years (statement 32); 
$H_{1}$ : Having an agriculture insurance coverage (statement 33) will change with the farmers' damage experience in the last three years (statement 32).

On the other hand, a statistically significant difference was found $[\mathrm{F}(1,219)=$ 7.711, $\mathrm{p}=0.006]$ therefore $\mathrm{H}_{1}$ is accepted, meaning that having agriculture insurance coverage will be influenced by the farmers' damage experience in the last three years.

$H_{0}$ : The intention of the farmers to take on greenhouse agricultural insurance coverage (statement 31) will not be influenced by the farmers ' Attitudes scale';

$H_{1}$ : The intention of the farmers to take on greenhouse agricultural insurance coverage (statement 31) will be influenced by the farmers' 'Attitudes scale'.

The 'Attitude' scale used in the study consisted of statements such as agricultural formalities, duration of insurance transactions, damage compensation level and insurance coverage. The one-way ANOVA results $[\mathrm{F}(18,201)=2,193, \mathrm{p}=0,009]$, shows that $\mathrm{H}_{1}$ can be accepted and that any change in the farmers 'Attitudes scale' create awareness on the need for insurance cover. Therefore, as the farmers' positive 'Attitudes scale' increases, the farmers' appetite for insurance cover increases and vice-versa.

$H_{0}$ : Having an agriculture insurance coverage (statement 33) will not be influenced by the farmers' 'Attitudes scale';

$H_{1}$ : Having an agriculture insurance coverage (statement 33) will be influenced by the farmers' 'Attitudes scale'.

According to ANOVA results $[\mathrm{F}(18,202)=2,059, \mathrm{p}=0,009]$, changes in the 'Attitudes scale' towards insurance policy ownership will make a difference. Therefore, $\mathrm{H}_{1}$ can be accepted and we can note that farmer 'attitudes' are an influencing factor on whether or not the farmer has an agriculture insurance coverage.

$H_{0}$ : The intention of the farmers to take on greenhouse agricultural insurance coverage (statement 31) will not be influenced by the farmers' 'Positivity scale';

$H_{l}$ : The intention of the farmers to take on greenhouse agricultural insurance coverage (statement 31) will be influenced by the farmers' 'Positivity scale'.

ANOVA analysis values $[\mathrm{F}(17,202)=0,606, \mathrm{p}=0,885]$ indicate that $\mathrm{H}_{0}$ can be accepted, meaning that a change in these farmers' 'Positivity scale' will not influence the intention of the farmers to take on greenhouse agricultural insurance coverage.

$H_{0}$ : Having an agriculture insurance coverage (statement 33) will not be influenced by the farmers' 'Positivity scale';

$H_{1}$ : Having an agriculture insurance coverage (statement 33) will be influenced by the 'Positivity scale'. 
ANOVA analysis values $[\mathrm{F}(17,203)=1,156, \mathrm{p}=0,304]$ indicate that $\mathrm{H}_{0}$ can be accepted, meaning that a change in these farmers' 'Positivity scale' will not influence the appetite for them to hold an insurance policy cover.

$H_{0}$ : The intention of the farmers to take on greenhouse agricultural insurance coverage (statement 31) will not be influenced by the farmers' 'Reasons scale';

$H_{1}$ : The intention of the farmers to take on greenhouse agricultural insurance coverage (statement 31) will be influenced by the farmers' 'Reasons scale';

$H_{0}$ : Having an agriculture insurance coverage (statement 33) will not be influenced by the farmers' 'Reasons scale';

$H_{1}$ : Having an agriculture insurance coverage (statement 33) will be influenced by the 'Reasons scale'.

ANOVA results show that changes in the farmers' 'Reasons scale' influential factors do not lead to a change in the farmers' appetite for insurance policy cover $[\mathrm{F}(16,203)=1,233, \mathrm{p}=0,385]$ and in the insurance policy ownership decision $[\mathrm{F}(16,204)=0,861, \mathrm{p}=0,614]$. Therefore, in both cases $\mathrm{H}_{0}$ is accepted.

$H_{0}$ : The intention of the farmers to take on greenhouse agricultural insurance coverage (statement 31) will not be influenced by the farmers' 'Obstacles scale';

$H_{1}$ : The intention of the farmers to take on greenhouse agricultural insurance coverage (statement 31) will be influenced by the farmers' 'Obstacles scale'.

ANOVA results $[\mathrm{F}(28,191)=1,597, \mathrm{p}=0,036]$ indicate that the farmers' perception about the presence of obstacles (in the 'Obstacle scale') influences the farmers' appetite to purchase agriculture insurance cover. Therefore, in both cases, $\mathrm{H}_{1}$ can be accepted.

$H_{0}$ : Having an agriculture insurance coverage (statement 33) ) will not be influenced by the farmers' 'Obstacles scale';

$H_{1}$ : Having an agriculture insurance coverage (statement 33) will be influenced by the farmers' 'Obstacles scale'.

However, ANOVA results $[\mathrm{F}(29,191)=1,029, \mathrm{p}=0,433]$ indicate that the farmers' perception about the presence of obstacles (in the 'Obstacle scale') does not have any influence on the farmers' decision to own insurance policy. Therefore, in both cases, $\mathrm{H}_{0}$ can be accepted.

$H_{0}$ : The intention of the farmers to take on greenhouse agricultural insurance coverage (statement 31) will not be influenced by the farmers' 'Facilitating scale'; $H_{1}$ : The intention of the farmers to take on greenhouse agricultural insurance coverage (statement 31) will be influenced by the farmers' 'Facilitating scale'; $H_{0}$ : Having an agriculture insurance coverage (statement 33) will not be influenced by the farmers' 'Facilitating scale'; 
$H_{l}$ : Having an agriculture insurance coverage (statement 33) will be influenced by the 'Facilitating scale'.

From the literature mentioned above, we note that some influential factors such as (1) the aid of agriculture insurance institutions, (2) lower insurance premiums, (3) fairness of insurance institutions and (4) cooperation between institutions; increases the farmers' appetite for greenhouse agricultural insurance policy cover. However, ANOVA analysis results indicate otherwise, therefore in both, $\mathrm{H}_{0}$ can be accepted meaning that these facilitating factors do not have any influence on the farmers' intention to purchase the insurance cover $[\mathrm{F}(15,204)=1,309, \mathrm{p}=0,199]$ and are not influential on the decision of farmers to own an insurance policy cover $[\mathrm{F}(15,205)=$ $0,896, \mathrm{p}=0,569]$.

\subsection{Official Data Analysis Findings}

No reported official data on the use of agriculture insurance in Demre has been found. According to Tarsim data ${ }^{6}$, the number of greenhouse agriculture insurance policies in 2017 in Turkey reached 1.493.392 Turkish Lira (TRY) (approximately $€ 247,800$ ) increasing by $9.3 \%$ on the previous year. Greenhouse agriculture insurance premium production of Turkey reached 1.160.546.158TRY (approximately $€ 192,662,267.69$ ) in 2017 with a rate of increase of $19.2 \%$.

According to the Tarsim activity report, these insurance premiums also increased in provinces with the increase in the number of insurance policy covers take-up and therefore the insurance premium production decreased in the provinces with a decrease in the number of these insurance policy cover.

In the Antalya province, where Demre is located, greenhouse insurance premium production decreased by $10.6 \%$ to $21.982 .272 \mathrm{TRY}$ (approximately $€ 3,649,276.97$ ) from 24.587.271TRY (approximately Euro4,081,732.86).

Delving deeper, into damage data obtained from the Demre Sub-Governorate and outlined in Table 4, it is understood that in 2016, $13.62 \%(9.79 \%+3,83 \%)$ of 235 farmers having Tarsim claimed for damages. During this period, $90.21 \%$ of the farmers were supported by the Prime Ministry funds. However, Tarsim payments did not cover the whole damage. The Tarsim coverage rate for some farmers was very low. For that reason, $3.83 \%$ of the farmers got additional payments from the Prime Ministry resources. In the tornado in 2017, 133 farmers claimed for damages. However, it was observed that the percentage of farmers who were covered by Tarsim decreased from $13.62 \%$ to $6.77 \%$ and those covered by public resources increased to $93.23 \%$ (Table 5).

\footnotetext{
${ }^{6}$ Tarsim 2017 Annual Report, p. 37.
} 
Table 5. The Number of Farmers Who Had Damages in Their Greenhouses in Demre Due to Tornados and the Distribution According to Damage Covering Sources

\begin{tabular}{|l|l|l|l|l|}
\hline Year & 2016 & 2017 & Rate \\
\hline $\begin{array}{l}\text { Damage Covering } \\
\text { Sources }\end{array}$ & Damage Number & Rate & $\begin{array}{l}\text { Damage } \\
\text { Number }\end{array}$ & 9 \\
\hline Tarsim & 23 & $9.79 \%$ & 9 & $6.77 \%$ \\
\hline Prime Ministry funds & 203 & $86.38 \%$ & 124 & $93.23 \%$ \\
\hline Additional Payment & 9 & $3.83 \%$ & 0 & $0.00 \%$ \\
\hline Total & 235 & $100.00 \%$ & 133 & $100.00 \%$ \\
\hline
\end{tabular}

Source: Demre District Governorship 2016 and 2017 Emergency Disaster Support Allowance Final Damage Assessment Reports.

The amount of payments for the damages of farmers after the tornados in 2016 and 2017 is indicated in Table 6. The payment rate for the damages in 2016 and 2017 is $35.25 \%$ and $23.91 \%$. Damage payment rates by Tarsim are $45.31 \%$ and $69.74 \%$ in 2016 and 2017. Damage payment rates by the Prime Ministry regressed to $20,97 \%$ from $31.3 \%$ in the first year.

When looking at Table 5 and Table 6, we can see that the number of farmers with Tarsim insurance and the amount of insured damage decreased. However, we can see that the number of uninsured farmers and the amount of uninsured damages increase. The insured damages rate was $22.80 \%(2.489 .000 / 10.918 .956)$ in the first year and decreased to $6.03 \%(616.738 / 10.229 .698)$ in the second year. When we look at these data, we find out that farmers' interest in the Tarsim system and the efficiency of the system decreased in the region.

Table 6. Nominal Value of the Damage in Greenhouses Due to Tornados in Demre and the Resources for Coverage

\begin{tabular}{|l|l|l|l|l|l|l|}
\hline Year & 2016 & \multicolumn{2}{l|}{2017} & \multicolumn{2}{l|}{} \\
\hline $\begin{array}{l}\text { Damage } \\
\text { Covering } \\
\text { Sources }\end{array}$ & $\begin{array}{l}\text { Damage } \\
\text { Amount } \\
(\mathrm{TRY})\end{array}$ & $\begin{array}{l}\text { Payment } \\
(\mathrm{TRY})^{*}\end{array}$ & $\begin{array}{l}\text { Payment } \\
\text { / Damage } \\
\text { Rate }\end{array}$ & $\begin{array}{l}\text { Damage } \\
\text { Amount } \\
(\mathrm{TRY})^{* *}\end{array}$ & $\begin{array}{l}\text { Payment } \\
(\mathrm{TRY})^{* *}\end{array}$ & $\begin{array}{l}\text { Payment } \\
\text { / Damage } \\
\text { Rate }\end{array}$ \\
\hline Tarsim & 2.489 .000 & 1.127 .736 & $45,31 \%$ & 616.738 & 430.086 & $69,74 \%$ \\
\hline $\begin{array}{l}\text { Prime } \\
\text { Ministry } \\
\text { funds }\end{array}$ & 8.429 .956 & 2.641 .140 & $31,30 \%$ & 9.612 .961 & 2.015 .708 & $20,97 \%$ \\
\hline $\begin{array}{l}\text { Additional } \\
\text { Payment }\end{array}$ & 0 & 79.657 & 0 & 0 & 0 & 0 \\
\hline Total & 10.918 .956 & 3.848 .533 & $35,25 \%$ & 10.229 .698 & 2.445 .794 & $23,91 \%$ \\
\hline
\end{tabular}

Source: Demre District Governorship 2016 and 2017 Emergency Disaster Support Allowance Final Damage Assessment Reports.

$* 2016$ average $\$ / T R Y$ sales price $=3.0277$, ** Average $\$ 2017 / \$$ sales rate $=3.6557$.

\subsection{Interview Findings}


As noted above, face-to-face open-ended interviews were conducted with 28 farmers in Demre. No further farmers were contacted for the interviews since 28 was the point of saturation (i.e. when no value added was being achieved from new interviews). Farmers were asked the reasons that kept them back from taking up greenhouse agriculture insurance cover. Names and details of farmers were kept anonymous and their answers were recorded on a notebook and later on MS word. A summary of the 10 top influential factors identified from the interviews using the thematic approach as explain by Braun et al. (2015) are outlined in Table 7 below.

As noted from the table above, the main problem faced by these farmers is that the greenhouses in the region are not modern enough and adequately equipped to be considered for insurance cover by underwriters. Insurance underwriters require that the owners of the greenhouses ensure such things as to (1) carry out physical improvements by surrounding the greenhouses with a concrete wall, (2) to guarantee that the greenhouses should only be used for a specified period of time and (3) guarantee that the nylon material does not have any problems.

However, as further noted there is insufficient income derived from product sales and capital to deal with these modernising requirements. Although $10.71 \%$ of farmers believe that the insurance premium amounts are high, they recommend that rather than requesting improvements, which cannot be adequately carried out, the underwriting premium for insurance cover should be increased to cater for the higher risk the insurers undertake.

Also, farmers highlight that the agricultural areas with title deed problems cannot be insured (78.57\%). Most of the agricultural area is rented and or in some inheritance dispute or belongs to one of the family members alone. Moreover, most of the greenhouse area is registered as an olive grove field, which is regarded as a complication by underwriters of insurance policies.

A further complication to this is that Farmers are obliged to be registered on the FRS system in order to take out greenhouse insurance. The registration process, (1) requires farmers to declare a title or rent contract for the greenhouse area, (2) to complete some formal procedures in official institutions such as the Chamber of Agriculture, the Land Registry, the Municipality, and (3) to pay periodic fees. If the ownership of the land is under dispute due to inheritance etc., no documents related to the greenhouse area can be obtained.

However, farmers believe that the insurance underwriter should not be requesting all this information and should focus on underwriting the greenhouse itself and not the surrounding field. 
Table 7. The top 10 influential Factors which keep Farmers back from taking up Greenhouse Agriculture Insurance cover, identified through the interview with Farmers

\begin{tabular}{|l|l|l|l|}
\hline & $\begin{array}{l}\text { Problems and Obstacles in Having Agricultural } \\
\text { Insurance }\end{array}$ & $\begin{array}{l}\text { Number of } \\
\text { observations }\end{array}$ & $\begin{array}{l}\text { Importance } \\
\text { level }\end{array}$ \\
\hline 1 & $\begin{array}{l}\text { Insurance companies will not insure since the } \\
\text { greenhouses may not be up to the standard required. }\end{array}$ & 24 & $85.71 \%$ \\
\hline 2 & $\begin{array}{l}\text { Greenhouse areas have title deeds problems and } \\
\text { therefore are not insurable. }\end{array}$ & 22 & $78.57 \%$ \\
\hline 3 & $\begin{array}{l}\text { Exclusions on insurance policies make the } \\
\text { payments in case of damage claims inadequate or } \\
\text { insufficient. }\end{array}$ & 22 & $71.43 \%$ \\
\hline 4 & $\begin{array}{l}\text { To become a member of the Farmer Registration } \\
\text { System, there many procedural bureaucracies, fees } \\
\text { and formalities to deal with, which lengthen the } \\
\text { process. }\end{array}$ & $\begin{array}{l}\text { In the case of natural disasters, it is considered } \\
\text { unfair that the state helps to cover the damages of } \\
\text { those who do not have insurance. }\end{array}$ & 17 \\
\hline 6 & $\begin{array}{l}\text { They lack the capital required to ensure that the } \\
\text { greenhouses are adequately equipped for insurance } \\
\text { requirements. }\end{array}$ & 16 & $67.86 \%$ \\
\hline 7 & $\begin{array}{l}\text { Insurance experts do not act fairly and do not carry } \\
\text { out adequate damage surveys }\end{array}$ & 12 & $42.86 \%$ \\
\hline 8 & Low revenue from product sales & 8 & $28.57 \%$ \\
\hline 9 & The insured covered period is limited & 3 & $14.28 \%$ \\
\hline 10 & Expensive insurance premiums & \\
\hline
\end{tabular}

Another problem is that the insurance coverage does not cover certain periods during the year and therefore the products are not covered by insurance during the whole agricultural period. Some farmers $(67.86 \%)$ argued that they find the fact that the state covers the damages from natural disasters of those who do not have insurance as unfair since while the uninsured receive support for damages from the state the insured party is not privy to this support. This also generally affects the farmers negatively about insurance.

Moreover, farmers argue that in the event of damage claims, the payments received under the greenhouse insurance cover are often insufficient to cover the damages. In some cases, no damage payment is made to the farmers on the grounds that the damage is excluded from the policy and some farmers are paid very low amounts such as 3-5 TRY (around Euro 0.50 to Euro 0.80), which is seen to be insulting and very unfair by farmers. It is also believed that the $50 \%$ of the premium paid for support by the State in Tarsim is excluded by the withdrawal at the time of the damage and $42.86 \%$ of the interviewed farmers believe that the insurance experts do not conduct sufficient damage inspections in case of damage and are not fair in their judgements. 


\section{Conclusions and Recommendations}

Findings from the survey indicate that close to half of the participants (56\%) have an appetite for taking on greenhouse agriculture insurance in the next year. Although farmers are aware of the risk, the interviews indicated that they do not take up these insurance covers because of the problems surrounding them such as (1) insurance formalities, (2) title deeds (3) etc.

In addition, findings indicate that the intention of the farmers to take on greenhouse agricultural insurance coverage is not influenced by factors relating to the experience of previous damages, positivity, reason, and facilitation. However, on the other hand, it is influenced by factors relating to the farmers' attitude and the obstacles they face. Moreover, findings show that the decision to own an insurance cover is not influenced by factors relating to positivity, reason, and facilitation and obstacles they face; but is influenced by factors relating to the farmers' experience of previous damages and the farmers' attitude.

Findings from the interview indicate that the support offered by the government to farmers after the tornado disasters have been one of the negative influencing factors reducing the farmers' appetite to take up insurance cover. After the disaster, the state helped only the farmers who did not have greenhouse agriculture insurance cover. This concurs with the findings by Tan et al.'s (2012).

Contrary to the findings in Malini (2011), it is also revealed that in general farmers in Demre are not happy with the greenhouse agriculture insurance policies and cover. In addition, contrary to the findings of Tsikirayi et al. (2013), farmers in Demre and insurance institutions do not communicate much and negotiated for common solution offers and there seems to be little transparency and comprehension between the too parties as suggested by Sibiko et al. (2017).

However, the biggest problem that farmers see as detrimental to taking an insurance coverage is the failure to meet the required obligatory changes requested by insurers and the issues with the property-title in the greenhouse areas besides the level of income, lack of capital resources and high insurance premiums. It is recommended that the ministry of agriculture, insurance institutions and farmers come together to discuss the problems and develop new practise standards and regulations that help to mitigate the issues highlighted herein.

Some suggestions derived after discussing with the farmers, that may help in increasing the appetite for insurance cover by farmers can be: (1) to provide farmers with access to soft loans to modernise their equipment and greenhouses and to help pay for insurance cover; (2) to establishment a farmer advisory center in which the farmers will be able to communicate their problems and lobby to address them; (3) to improve the quality and modernise the greenhouses; (4) to ensure that regardless of the ownership, products and greenhouses of the farmers' cultivatings in the 
relevant fields should be covered by the insurance; (5) to register all greenhouses on the FRS system (6) to revise the state disaster relief for farmers; (7) to provide continuous trainings to farmers.

\section{References:}

Akçaöz, H., Özkan, B., Kızılay, H. 2006. Risk management and agricultural insurance practices in agricultural production in Antalya Province. JOTAF / Tekirdag Agricultural Journal, 3(2), 93-103.

Aydın, G., Koc, E. 2016. Social Marketing Analysis of Attitude Toward Compulsory Earthquake Insurance in Turkey. Management and Economics: Celal Bayar University Journal of the Faculty of Economics and Administrative Sciences, 23(2), 389-407.

Baldacchino, P.J., Camilleri, C., Grima, S., Bezzina, F., 2017. Assessing incentive and monitoring schemes in the corporate governance of Maltese cooperatives. European Research Studies Journal, 20(3A), 179-197.

Baldacchino, P.J., Abela, M., Grima, S., 2018. Assessing incentive and monitoring schemes in the corporate governance of Maltese cooperatives. European Research Studies Journal, 21(4), 1-13.

Baglin, J. 2014. Improving your exploratory factor analysis for ordinal data: a demonstration using FACTOR. Practical Assessment, Research \& Evaluation, 19(5), 2-15.

Braun, V., Clarke, V. 2006. Using thematic analysis in psychology. Qualitative Research in Psychology, 3(2), 77-101.

Grima, S., Seychell, S., Bezzina, F., 2017. Investigating Factors Predicting Derivative Mishandling: A Sociological Perspective. European Research Studies Journal, 20(4A), 3-17.

Hamarat, B., 2017. SPSS and MINITAB Applied Statistics, Paradikma Publishing. 1st Edition.

Hornby, P., Symon, G. 1994. Tracer studies, in C. Casselland and G. Symon (eds) Qualitative methods in Organisational Research: A Practical Guide. Sage, 167-186, London.

Jin, J., Wang, W., Wang, X. 2016. Farmers' risk preferences and agricultural weather index insurance uptake in rural China. International Journal of Disaster Risk Science, 7(4), 366-373.

Kim, C., Tao, W., Shin, N., Kim, K.S. 2010. An empirical study of customers' perceptions of security and trust in e-payment systems. Electronic commerce research and applications, 9(1), 84-95.

Koc, E., Boz, H. 2014. Triangulation in tourism research: A bibliometric study of top three tourism journals. Tourism Management Perspectives, 12, 9-14.

Malini, R. 2011. The attitude of Farmers Toward Agriculture Insurance: A Study with Special Reference to Ambasamudram Area of Tamil Nadu. IUP Journal of Agricultural Economics, 8(3), 24-37.

Morse, J.M. 1995. The significance of saturation. Qualitative Health Research, 5(3), 147 149.

Nikolov, D., Anastasova-Chopeva, M., Ivanova, E. 2013. Insurance products in agriculture and farm insurance behaviour. Economic Thought journal, (1), 62-83.

Sibiko, K.W.. Veettil, P.C., Qaim, M. 2017. Small farmers' preferences for weather index insurance: Insights from Kenya, Global Food Discussion Papers, No. 93. 
Tan, S., Everest, B., Özen, A. 2012. Investigation of producers' demands and tendencies on agricultural insurance: The example of Çanakkale Province Lâpseki District. National Agricultural Economics Congress, Konya, 5-7.

Tongco, MD.C. 2007. Purposive Sampling as a Tool for Informant Selection Dolores C.T. file:///E:/Desktops/Old\%20\%20Desktop\%20-

\%20Main/University/Thesis\%20at\%20the \%20UOM/Research\%20methods/Qualitative \%20sample\%20size/126-454-1-PB.pdf.

Tsikirayi, C.M.R., Makoni, E., Matiza, J. 2012. Analysis of the uptake of agricultural insurance services by the agricultural sector in Zimbabwe. Journal of International Business and Cultural Studies, 7, 1-14.

\begin{tabular}{|c|c|c|}
\hline \multicolumn{3}{|c|}{ Annex: Survey } \\
\hline & Variables & Statements \\
\hline 1 & Attitude 1 & Tarsim Insurance is cheaper. \\
\hline 2 & Attitude 2 & Not many formalities are required to obtain Tarsim cover. \\
\hline 3 & Attitude 3 & Tarsim Insurance cover is easily obtained and quick. \\
\hline 4 & Attitude 4 & $\begin{array}{l}\text { The guidance of the Tarsim officials increases my willingness } \\
\text { to take on a Tarsim insurance. }\end{array}$ \\
\hline 5 & Attitude 5 & Tarsim meets all claims for damages as set out in the agreement. \\
\hline 6 & Attitude 6 & $\begin{array}{l}\text { Tarsim has a wide and flexible scope, which can respond to } \\
\text { various types of agricultural insurance requirements. }\end{array}$ \\
\hline 7 & Attitude 7 & Insurance experts are able to solve problems and act fairly. \\
\hline 8 & Positivity 1 & Farmers are able to market their products well. \\
\hline 9 & Positivity 2 & $\begin{array}{l}\text { Farmers have sufficient technological tools to ensure a better } \\
\text { crop. }\end{array}$ \\
\hline 10 & Positivity 3 & Labour costs are reasonable. \\
\hline 11 & Positivity 4 & Our products are sold at good rates. \\
\hline 12 & Reason 1 & $\begin{array}{l}\text { A high risk of climate-related damage in the future increases my } \\
\text { desire to insure. }\end{array}$ \\
\hline 13 & Reason 2 & $\begin{array}{l}\text { The support and execution of Tarsim by the state increases my } \\
\text { desire to take up insurance cover. }\end{array}$ \\
\hline 14 & Reason 3 & $\begin{array}{l}\text { Natural events such as storm damage to the products increase } \\
\text { my desire take up insurance cover. }\end{array}$ \\
\hline 15 & Reason 4 & $\begin{array}{l}\text { The partial coverage of Tarsim premiums by the government } \\
\text { increases my desire take up insurance cover. }\end{array}$ \\
\hline 16 & Obstacle 1 & $\begin{array}{l}\text { Land rent is an obstacle to the take up of Tarsim insurance } \\
\text { cover. }\end{array}$ \\
\hline 17 & Obstacle 2 & $\begin{array}{l}\text { The lack of technical knowledge about agricultural insurance is } \\
\text { an obstacle to the take up of Tarsim insurance cover. }\end{array}$ \\
\hline 18 & Obstacle 3 & $\begin{array}{l}\text { Inadequate calculation and accounting information related to } \\
\text { insurance is an obstacle to the take up of Tarsim insurance } \\
\text { cover. }\end{array}$ \\
\hline 19 & Obstacle 4 & $\begin{array}{l}\text { The lack of money / financial resources is an obstacle to the } \\
\text { take up of Tarsim insurance cover. }\end{array}$ \\
\hline 20 & Obstacle 5 & $\begin{array}{l}\text { Failure to introduce Tarsim insurance is an obstacle to the take } \\
\text { up of Tarsim insurance cover. }\end{array}$ \\
\hline 21 & Obstacle 6 & The possibility of damage payments being irregular/insufficient \\
\hline
\end{tabular}




\begin{tabular}{|l|l|l|}
\hline $\mathbf{2 2}$ & Obstacle 7 & $\begin{array}{l}\text { is an obstacle to the take up of Tarsim insurance cover } \\
\text { insurance cover. }\end{array}$ \\
\hline $\mathbf{2 3}$ & Obstacle 8 & $\begin{array}{l}\text { The complexity of legal procedures in the insurance process is } \\
\text { an obstacle to the take up of Tarsim insurance cover }\end{array}$ \\
\hline $\mathbf{2 4}$ & Obstacle 9 & $\begin{array}{l}\text { Having legal problems with the title deed is an obstacle to the } \\
\text { take up of Tarsim insurance cover. }\end{array}$ \\
\hline $\mathbf{2 5}$ & Facilitating 1 & $\begin{array}{l}\text { Help by institutions such as the chamber of agriculture in } \\
\text { fulfilling some legal procedures would increase my desire to } \\
\text { take up Tarsim insurance cover. }\end{array}$ \\
\hline $\mathbf{2 6}$ & Facilitating 2 & $\begin{array}{l}\text { Lower insurance premiums would increase my desire to take up } \\
\text { Tarsim insurance cover. }\end{array}$ \\
\hline $\mathbf{2 7}$ & Facilitating 3 & $\begin{array}{l}\text { Fairer insurance institutions would increase my desire to take up } \\
\text { Tarsim insurance cover. }\end{array}$ \\
\hline $\mathbf{2 9}$ & Facilitating 4 & $\begin{array}{l}\text { Collaboration with local institutions such as the chamber of } \\
\text { agriculture would increase my desire to take up Tarsim } \\
\text { insurance cover. }\end{array}$ \\
\hline $\mathbf{3 0}$ & Advisory Service & $\begin{array}{l}\text { Improving the scope of insurance products to meet the needs of } \\
\text { the farmer would increase my desire to take up Tarsim } \\
\text { insurance cover. }\end{array}$ \\
$\begin{array}{l}\text { The establishment of a farmer advisory centre to help with } \\
\text { listening to, solving problems and lobbying between the } \\
\text { government, insurance firms and the farmers would increase my } \\
\text { desire to take up Tarsim insurance cover. }\end{array}$ \\
\hline Intention & \begin{tabular}{l} 
I'm thinking about taking up a Tarsim Insurance cover next year \\
\hline
\end{tabular}
\end{tabular}

32- Have you had any damages in the last 3 years due to Rain-Tornado etc? No ( ), Yes ( )

33- Do you currently have a Tarsim insurance cover?

No ( ), Yes

( )

34- Did you get Tarsim insurance cover in the last 3 years?

No ( ), Yes

( )

35- In which age group do you fit a-) $18-30(\ldots)$ b-) $31-45(\ldots$.$) \quad c-) 46-60(\ldots$.$) d-)$ $61+(\ldots$. 